\title{
HUBUNGAN ANTARA LOCUS OF CONTROL DAN PERSEPSI PESERTA DIDIK TENTANG PENDIDIKAN DENGAN MOTIVASI BELAJAR SERTA IMPLIKASINYA DALAM PELAYANAN BIMBINGAN DAN KONSELING
}

\author{
Mona Yulia Zulfa ${ }^{1}$ \\ Daharnis $^{2}$ \\ Syahniar $^{3}$
}

\begin{abstract}
Abstrak
Latar belakang dari penelitian ini adalah kurangnya motivasi belajar peserta didik. Locus of control dan persepsi peserta didik tentang pendidikan merupakan faktor yang dapat memprediksi motivasi belajar peserta didik. Penelitian ini bertujuan untuk mendeskripsikan: (1) locus of control, (2) persepsi peserta didik tentang pendidikan, (3) motivasi belajar, dan menguji: (4) hubungan antara locus of control dengan motivasi belajar (5) persepsi peserta didik tentang pendidikan dengan motivasi belajar, dan (6) hubungan antara locus of control dan persepsi peserta didik tentang pendidikan dengan motivasi belajar. Penelitian ini menggunakan metode kuantitatif dengan deskriptif korelasional. Populasi penelitian ini adalah 623 peserta didik SMA Pertiwi 1 Padang pada kelas X dan XI dan sampel sebanyak 243 peserta didik, yang dipilih dengan teknik proportional stratified random sampling. Instrumen penelitian ini adalah model skala likert. Uji validitas hasil instrumen locus of control adalah 0,405 , persepsi peserta didik tentang pendidikan adalah 0,631 , dan motivasi belajar adalah 0,615 . Hasil uji reliabilitas instrumen locus of control adalah 0,747 , persepsi peserta didik tentang pendidikan sebesar 0,944, dan motivasi belajar sebesar 0,925. Data dianalisis dengan menggunakan statistik deskriptif, regresi sederhana dan multiple. Temuan penelitian menunjukkan bahwa: (1) Rata-rata, deskripsi locus of control internal peserta didik berada pada kategori sedang, (2) persepsi peserta didik tentang pendidikan pada kategori sangat positif, (3) motivasi belajar pada kategori tinggi, (4) terdapat hubungan yang signifikan antara persepsi peserta didik tentang pendidikan dengan motivasi belajar $(\mathrm{R}=0,432),(5)$ terdapat hubungan yang signifikan antara locus of control dan (6) persepsi peserta didik tentang pendidikan dengan motivasi belajar $(\mathrm{R}=0,449)$. Implikasi dari penelitian ini dapat dijadikan sebagai program pelayanan bimbingan dan konseling di SMA Pertiwi 1 Padang.
\end{abstract}

Kata kunci: Locus of Control, Persepsi peserta didik tentang Pendidikan, Motivasi Belajar

\begin{abstract}
The background of this research was the lack of student's learning motivation. Locus of control and student's perception about education became factors that can predict student's learning motivation. This research is aimed to describe: (1) locus of control, (2) student's perception about education, (3) learning motivation, and examine: (4) the relationship between locus of control with learning motivation,
\end{abstract}

\footnotetext{
${ }^{1}$ Mahasiswa Program Studi S2 Bimbingan dan Konseling Email: monayuliazulfa@gmail.com.

${ }^{2}$ Dosen Program Studi S2 Bimbingan dan Konseling, Fakultas Ilmu Pendidikan Universitas Negeri Padang

${ }^{3}$ Dosen Program Studi S2 Bimbingan dan Konseling, Fakultas Ilmu Pendidikan Universitas Negeri Padang
} 
(5) the relationship between student's perception about education with learning motivation, and (6) the relationship between locus of control and student's perception about education with learning motivation. This research applied quantitative method with a descriptive correlational. The populations of this research were 623 students of SMA Pertiwi 1 Padang in grade X and XI and the samples were 243 students, that were chosen by using proportional stratified random sampling technique. The instrument of the research was a model likert scale. Validity test result of this locus of control's instrument was 0.405 , student's perception about education was 0.631 , and learning motivation was 0.615. Reliability test result of locus of control's instrument was 0.747 , student's perception about education was 0.944, and learning motivation was 0.925 . The data were analized by using descriptive statistics, simple and multiple regression. The research findings indicated that: (1) averagely, description of the student's internal locus of control was at moderate category, (2) student's perception about education was at very positive category, (3) learning motivation was at high category, (4) there was a significant relationship between locus of control with learning motivation $(R=0.200)$, (5) there was a significant relationship between student's perception about education with learning motivation $(R=0.432)$, (6) there were together a significant relationship between locus of control and student's perception about education with learning motivation $(R=0.449)$. The implication of this research can be made as a need assessment to make a program of guidance dan counseling service in SMA Pertiwi 1 Padang.

Keywords: Locus of Control, Student's Perception about Education, Learning Motivation

\section{PENDAHULUAN}

Pada masa sekarang ini generasi muda diharuskan memiliki pengetahuan yang tinggi sehinggatidakketinggalan dalamperkembangan zaman. Seseorang harus memiliki kualitas yang baik dalam segala aspek karena semakin tingginya tuntutan dan persaingan dunia kerja yang membutuhkan sumber daya manusia yang berkualitas. Peningkatan sumber daya manusia salah satunya melalui pendidikan. Pendidikan merupakan proses mencetak generasi penerus bangsa yang akan membantu dalam kemajuan Negara. Tidak dapat dibayangkan jika penerus bangsa ini tidak memiliki pendidikan yang layak maka kemajuan negara akan sulit tercapai. Pendidikan pada hakikatnya bertujuan untuk menciptakan sumber daya manusia yang mandiri dan berkompetensi dalam mengisi dan berpartisipasi aktif dalam pembangunan nasional.

Tujuan pendidikan memuat nilai-nilai yang baik, luhur, pantas, benar, dan indah untuk kehidupan. Karena itu, tujuan pendidikan memiliki dua fungsi yaitu memberikan arah kepada segenap kegiatan dan merupakan sesuatu yang ingin dicapai oleh segenap kegiatan pendidikan (Tirtarahardja dan La Sulo, 2008). Pencapaian tujuan pendidikan tersebut salah satunya adalah melalui pendidikan di sekolah. Dalam keseluruhan proses pendidikan di sekolah, kegiatan belajar merupakan kegiatan paling pokok. Sekolah sebagai lembaga pendidikan formal mempunyai tugas menyelenggarakan pendidikan melalui proses pembelajaran untuk mengembangkan aspek kemanusiaan dan potensi diri peserta didik, sehingga peserta didik nantinya dapat berkembang sesuai dengan potensi yang dimilikinya. Hal ini tentunya tidak terlepas dari motivasi peserta didik itu sendiri dalam menjalani pendidikan tersebut.

Crider dkk. (1983) menjelaskan bahwa, "Motivation can be defined as the desires, needs, and interests that arouse or activate an organism and direct it toward a specific goal, can lead to many different behaviors". Motivasi dapat didefinisikan sebagai keinginan, kebutuhan, dan kepentingan yang membangkitkan atau mengaktifkan suatu 
organisme dan mengarahkan ke arah tujuan tertentu, dapat menyebabkan banyak perilaku yang berbeda. Lebih lanjut motivasi menurut Mangkuprawira dan Hubeis (2007) merupakan dorongan yang membuat individu melakukan sesuatu dengan cara dan untuk mencapai tujuan tertentu. Motivasi dalam bahasa Inggris disebut motivation yang berasal dari bahasa latin movere yang berarti menggerakkan. Adanya motivasi yang tinggi dari peserta didik diharapkan mampu menggerakkan minat peserta didik untuk menjadikan sekolah bukan hanya sebagai tuntutan namun juga merupakan kebutuhan bagi dirinya.

Berdasarkan pendapat para ahli di atas, dapat disimpulkan bahwa motivasi merupakan suatu dorongan dari dalam diri individu dan luar diri individu yang menyebabkan individu bergerak untuk melakukan suatu hal dalam mencapai hasrat dan tujuan tertentu. Dalam hal belajar, motivasi diartikan sebagai keseluruhan daya penggerak dalam diri peserta didik untuk melakukan serangkaian kegiatan belajar guna mencapai tujuan yang telah ditetapkan.

Sekolah memiliki visi dan misi untuk meningkatkan motivasi belajar dan juga prestasi belajar peserta didik atau meningkatkan sumber daya manusia, tetapi pada kenyataannya banyak peserta didik yang tidak memperhatikan hal tersebut, mereka menganggap sekolah itu sebagai ajang bertemu teman-teman dan bisa keluar dari rumah saja tanpa memperhatikan apa sesungguhnya yang mereka cari ke sekolah, dan kenyataan tersebut ditemui di SMA Pertiwi 1 Padang. Sehubungan dengan motivasi belajar peserta didik beberapa tahun belakangan ini, muncul beberapa fenomena atau gelaja yang memprihatinkan, seperti terlihat pada absensi peserta didik dalam mengikuti proses pembelajaran, banyaknya peserta didik yang alfa, sering terlambat untuk datang ke sekolah, dan cabut ketika proses pembelajaran berlangsung.

Berdasarkan hasil obeservasi, terlihat banyaknya peserta didik yang keluar masuk ketika proses pembelajaran berlangsung, banyak yang pergi ke kedai dan minta izin kepada guru BK untuk duduk di ruangan BK, dan ketika mereka diberi tugas oleh guru, kebanyakan mereka tidak mengerjakan tugas tersebut. Setelah diwawancarai, kebanyakan mereka menjawab karena mereka bosan dalam belajar. Hal ini menunjukkan bahwa rendahnya motivasi belajar peserta didik.

Beberapa hal yang diduga menjadi faktor yang mempengaruhi motivasi belajar seperti yang dikemukakan oleh Elliott dkk. (1996) yaitu anxiety (kecemasan), attitudes (sikap), curiosity (keingintahuan), locus of control (sejauhmana seseorang merasa bahwa dirinya atau faktor dari luar dirinya dapat mengendalikan peristiwa yang terjadi dan mempengaruhi kehidupan), learned helplessness (kekurangmampuan dalam belajar), self efficacy (keyakinan diri), dan cooperative learning (pembelajaraan kooperatif).

Suryabrata (2012) menyatakan bahwa salah satu faktor yang mempengaruhi motivasi belajar adalah persepsi. Tinggi rendahnya motivasi belajar peserta didik juga dapat dipengaruhi oleh bagaimana individu memandang peristiwa-peristiwa dalam kehidupannya sebagai konsekuensi perbuatannya (locus of control). Locus of control menggambarkan seberapa jauh individu memandang hubungan antara perbuatan yang dilakukannya dengan akibat atau hasil yang dicapainya. Rotter (dalam Loice, 2014) menjelaskan, "Locus of control as the extent to which people perceive that them or external factors such as chance and powerful others are in control of the events that influence their lives". Locus of control adalah sejauhmana seseorang merasa bahwa dirinya atau faktor dari luar dirinya seperti kesempatan dan kekuatan lain, dapat mengendalikan peristiwa yang terjadi dan mempengaruhi kehidupan mereka. Locus of control mempengaruhi motivasi belajar terlihat juga dari hasil penelitian Mugiarso dan Suharso (2013) bahwa seseorang yang cenderung memiliki locus of control internal, berarti seseorang tersebut memiliki motivasi yang tinggi.

Locus of control terdiri dari dua dimensi 
yaitu internal dan eksternal. peserta didik yang memiliki kecenderungan locus of control internal meyakini bahwa kesuksesan dan kegagalannya dalam belajar adalah hasil dari tindakan dan usaha mereka sendiri (Rotter, 1996). Contohnya ketika peserta didik memiliki nilai yang rendah meyakini bahwa tidak belajar dengan optimal, bukan karena gurunya yang pilih kasih. Sebaliknya peserta didik yang memiliki kecenderungan locus of control eksternal akan meyakini bahwa kesuksesan dan kegagalannya adalah karena faktor di luar dirinya.

Faktor lain yang juga mempengaruhi motivasi belajar peserta didik adalah persepsi peserta didik itu sendiri tentang pendidikan. Menurut Leavitt (dalam Sobur, 2003), persepsi (perception) dalam arti sempit ialah penglihatan, bagaimana cara seseorang melihat sesuatu, sedangkan dalam arti luas ialah pandangan atau pengertian, yaitu bagaimana seseorang memandang atau mengartikan sesuatu. Persepsi menurut Feldmen, Sternberg, dan Robbins (dalam Nirwana, 2003) merupakan proses ketika individu mengorganisasikan, mengenal, dan memaknai sensasi yang diperolehnya dari lingkungan. Maksud dari pernyataan tersebut adalah persepsi merupakan bagaimana seseorang memandang dan memaknai suatu hal yang diperoleh dari lingkungan.

Berkaitan dengan sekolah, persepsi peserta didik tentang pendidikan dijelaskan sebagai pandangan atau anggapan peserta didik mengenai pendidikan itu sendiri, bagus atau tidaknya pendidikan tersebut. Persepsi peserta didik tentang pendidikan yang tidak positif akan membuat kurangnya motivasi peserta didik dalam belajar, begitu juga sebaliknya persepsi peserta didik yang positif tentang pendidikan akan membuat motivasi belajar peserta didik yang tinggi juga. Hal ini senada dengan hasil penelitian dari Megawati (2015), yang menyatakan bahwa semakin positif persepsi peserta didik, maka akan semakin menumbuhkan motivasi belajar yang tinggi pada peserta didik, dan semakin tidak positif persepsi peserta didik, maka akan semakin rendah juga motivasi belajar peserta didik tersebut. Dapat disimpulkan bahwa salah satu faktor yang mempengaruhi motivasi belajar adalah persepsi peserta didik tentang pendidikan.

Berdasarkan penjelasan di atas, dapat disimpulkan bahwa motivasi belajar menjadi hal yang sangat perlu diperhatikan dan penting. Oleh karena itu, bimbingan dan konseling memiliki peranan yang penting dalam usaha membantu peserta didik untuk meningkatkan locus of control internal dan persepsi yang positif tentang pendidikan, yang bertujuan agar peserta didik memiliki motivasi belajar yang tinggi. Hal ini dapat dilakukan dengan pelaksanaan layanan bimbingan dan konseling kepada peserta didik, seperti: layanan orientasi, layanan informasi, layanan konseling perorangan, bimbingan kelompok, dan layanan lainnya. Dalam pelaksanaan layanan konseling tersebut, konselor harus mengetahui berbagai faktor yang mempengaruhi motivasi belajar pada peserta didik, diantaranya locus of control dan persepsi peserta didik tentang pendidikan. Untuk membuktikan seberapa besar hubungan dari faktor-faktor tersebut dalam meningkatkan motivasi belajar peserta didik, peneliti tertarik untuk melakukan penelitian tentang hubungan antara locus of control dan persepsi peserta didik tentang pendidikan dengan motivasi belajar peserta didik serta implikasinya dalam pelayanan bimbingan dan konseling.

Tujuan penelitian ini yaitu: mendeskripsikan gambaran locus of control, persepsi peserta didik tentang pendidikan, dan motivasi belajar peserta didik, (2) menguji hubungan antara locus of control dengan motivasi belajar peserta didik, (3) menguji hubungan antara persepsi peserta didik tentang pendidikan dengan motivasi belajar peserta didik, (4) menguji hubungan antara locus of control dan persepsi peserta didik tentang pendidikan secara bersama-sama dengan motivasi belajar peserta didik.

\section{METODOLOGI}

Penelitian ini menggunakan metode 
kuantitatif jenis deskriptif korelasional. Populasi penelitian adalah peserta didik kelas X dan XI SMA Pertiwi 1 Padang yang berjumlah 623 orang, sampel berjumlah 243 orang, yang dipilih dengan teknik proportional stratified random sampling. Instrumen yang digunakan adalah skala model likert. Data dianalisis dengan statistik deskriptif, regresi sederhana dan ganda. Analisis data dibantu dengan menggunakan program SPSS versi 20.00 .

\section{HASIL PENELITIAN}

\section{Deskripsi Data}

Data dalam penelitian ini meliputi variabel locus of control $\left(\mathrm{X}_{1}\right)$, persepsi peserta didik tentang pendidikan $\left(\mathrm{X}_{2}\right)$, dan motivasi belajar (Y). Berikut ini dikemukakan deskripsi data hasil penelitian.

\section{Locus of Control $\left(\mathbf{X}_{1}\right)$}

Secara keseluruhan jumlah item pernyataan variabel locus of control ada sebanyak 24 butir item, rentangan skor dari 1-5, dengan skor tertinggi adalah 120 dan skor terendah adalah 24. Kriteria skala locus of control yang berjumlah 243 responden dapat dilihat pada Tabel 1.

\begin{tabular}{clcc}
\hline $\begin{array}{c}\text { Interval } \\
\text { Skor }\end{array}$ & Kategori & Frekuensi & \% \\
\hline$\geq 101$ & Sangat Tinggi & 0 & 0 \\
$82-100$ & Tinggi & 116 & 47,74 \\
$63-81$ & Sedang & 127 & 52,26 \\
$44-62$ & Rendah & 0 & 0 \\
$\leq 43$ & Sangat Rendah & 0 & 0 \\
Total & & 243 & 100 \\
\hline
\end{tabular}

Tabel 1. Distribusi Frekuensi dan Persentase Locus of Control

Tabel 1 di atas memperlihatkan bahwa sebagian besar peserta didik memiliki locus of control dalam kategori sedang. Namun demikian, masih terdapat variasi skor dalam indikator locus of control.

\section{Persepsi peserta didik tentang Pendidikan $\left(\mathrm{X}_{2}\right)$}

Secara keseluruhan jumlah item pernyataan variabel persepsi peserta didik tentang pendidikan ada sebanyak 30 butir item, rentangan skor dari 1-5, dengan skor tertinggi adalah 150 dan skor terendah adalah 30 . Kriteria skala persepsi peserta didik tentang pendidikan yang berjumlah 243 responden dapat dilihat pada Tabel 2.

\begin{tabular}{clcc}
\hline $\begin{array}{c}\text { Interval } \\
\text { Skor }\end{array}$ & \multicolumn{1}{c}{ Kategori } & Frekuensi & $\%$ \\
\hline$\geq 126$ & Sangat Positif & 150 & 62 \\
$102-125$ & Positif & 84 & 34,57 \\
$43-56$ & Cukup Positif & 9 & 3,70 \\
$29-42$ & Tidak Positif & 0 & 0 \\
$\leq 28$ & Sangat Tidak Positif & 0 & 0 \\
& Total & 243 & 100 \\
\hline Tabel 2. Distribusi Frekuensi dan Persentase Persepsi peserta
\end{tabular}
didik Pendidikan

Tabel 2 di atas memperlihatkan bahwa sebagian besar peserta didik memiliki persepsi yang sangat positif tentang pendidikan. Namun demikian, masih terdapat variasi skor dalam indikator persepsi peserta didik tentang pendidikan.

\section{Motivasi Belajar (Y)}

Secara keseluruhan jumlah item pernyataan variabel persepsi peserta didik tentang pendidikan ada sebanyak 26 butir item, rentangan skor dari 1-5, dengan skor tertinggi adalah 130 dan skor terendah adalah 26 . Kriteria skala motivasi belajar yang berjumlah 243 responden dapat dilihat pada Tabel 3.

\begin{tabular}{clcc}
\hline $\begin{array}{c}\text { Interval } \\
\text { Skor }\end{array}$ & \multicolumn{1}{c}{ Kategori } & Frekuensi & \% \\
\hline$\geq 110$ & Sangat Tinggi & 29 & 12 \\
$89-109$ & Tinggi & 103 & 42,39 \\
$68-88$ & Sedang & 103 & 42,39 \\
$47-67$ & Rendah & 8 & 3.29 \\
$\leq 46$ & Sangat Rendah & 0 & 0 \\
& Total & 243 & 100 \\
\hline
\end{tabular}

Tabel 3. Distribusi Frekuensi dan Persentase Motivasi Belajar 
Tabel 3 di atas memperlihatkan bahwa sebagian besar motivasi belajar berada pada kategori tinggi dan sedang. Secara rata-rata capaian terhadap skor ideal adalah berada pada kategori tinggi. Namun demikian, masih terdapat variasi skor dalam indikator motivasi belajar.

\section{Pengujian Persyaratan Analisis Data}

Uji persyaratan analisis yang dilakukan pada data penelitian ini adalah uji normalitas, uji linieritas, dan uji multikolinieritas.

\section{Uji Normalitas}

Hasil uji normalitas data menggunakan uji Kolmogorov-Smirnov, dengan nilai Asymp. Sig. locus of control sebesar 0,079 , persepsi peserta didik tentang pendidikan sebesar 0,264, dan motivasi belajar sebesar 0,292. Berarti ketiga data variabel penelitian berdistribusi normal.

\section{Uji Linieritas}

Berdasarkan hasil uji linieritas, didapatkan hasil bahwa hubungan locus of control dengan motivasi belajar adalah linier dengan $\mathrm{F}_{\text {hitung }}$ $(10,774)>F_{\text {tabel }}(3,89)$. Data hubungan persepsi peserta didik tentang pendidikan dengan motivasi belajar juga linier dengan $\mathrm{F}_{\text {hitung }}$ $(54,722)>\mathrm{F}_{\text {tabel }}(3,89)$.

\section{Uji Multikolinieritas}

Hasil uji multikolinieritas menunjukkan bahwa tidak terjadi multikolinieritas antara variabel locus of control dengan persepsi peserta didik tentang pendidikan, dengan nilai VIP locus of control sebesar 1,033 dan nilai $V I P$ persepsi peserta didik tentang pendidikan sebesar $1,033<5$.

\section{Hubungan antara Locus of Control dan Persepsi peserta didik tentang Pendidikan dengan Motivasi Belajar}

\section{Hubungan antara Locus of Control dengan Motivasi Belajar}

Hasil analisis hubungan antara locus of control dengan motivasi belajar dapat dilihat pada Tabel 4.

\begin{tabular}{cccc}
\hline Model & $\mathbf{R}$ & $\boldsymbol{R}$ Square & Sig. \\
\hline $\mathrm{X}_{1}-\mathrm{Y}$ & 0,200 & 0,040 & 0,002 \\
\hline Tabel 4. Hasil Analisis Regresi Sederhana dan Uji \\
Signifikansi X1 dengan Y
\end{tabular}

Pada Tabel 4 dapat dilihat bahwa nilai $\mathrm{R}$ sebesar 0,200 yang menunjukkan koefisien korelasi antara locus of control dengan motivasi belajar, dengan taraf signifikan 0,002 . Nilai $R$ Square $\left(R^{2}\right)$ sebesar 0,040 ini berarti $4 \%$ variasi tinggi-rendahnya motivasi belajar dapat dijelaskan oleh locus of control, sedangkan sisanya $96 \%$ dijelaskan oleh variabel lain.

\section{Hubungan antara Persepsi peserta didik tentang Pendidikan dengan Motivasi Belajar}

Hasil analisis hubungan antara persepsi peserta didik tentang pendidikan dengan motivasi belajar dapat dilihat pada Tabel 5 .

\begin{tabular}{|c|c|c|c|}
\hline Model & $\mathbf{R}$ & R Square & Sig. \\
\hline $\mathrm{X}_{2}-\mathrm{Y}$ & 0,432 & 0,186 & 0,000 \\
\hline
\end{tabular}

Pada Tabel 5 dapat dilihat bahwa nilai $\mathrm{R}$ sebesar 0,432 yang menunjukkan koefisien korelasi antara persepsi peserta didik tentang pendidikan dengan motivasi belajar, dengan taraf signifikan 0,000 . Nilai $R$ Square $\left(R^{2}\right)$ sebesar 0,186 , ini berarti $18,6 \%$ variasi tinggi rendahnya motivasi belajar dapat dijelaskan oleh persepsi peserta didik tentang pendidikan, sedangkan sisanya $81,4 \%$ dijelaskan oleh variabel lain.

\section{Hubungan antara Locus of Control dan Persepsi peserta didik tentang Pendidikan dengan Motivasi Belajar}

Hasil analisis hubungan antara locus of control dan persepsi peserta didik tentang pendidikan dengan motivasi belajar dapat dilihat pada Tabel 6 . 


\begin{tabular}{lrrl}
\hline & & & \\
\hline Model & $\mathbf{R}$ & $\boldsymbol{R}$ Square & Sig. \\
\hline $\mathrm{X}_{1}, \mathrm{X}_{2}-\mathrm{Y}$ & 0,449 & 0,202 & 0,000 \\
\hline
\end{tabular}

Tabel 6. Hasil Analisis Regresi Ganda dan Uji Signifikansi $\mathrm{X}_{1}$ dan $\mathrm{X}_{2}$ dengan $\mathrm{Y}$

Pada Tabel 6 dapat dilihat bahwa nilai $\mathrm{R}$ sebesar 0,449 yang menunjukkan koefisien regresi ganda antara locus of control dan persepsi peserta didik tentang pendidikan dengan motivasi belajar, dengan taraf signifikan 0,000 . Nilai $R$ Square $\left(R^{2}\right)$ sebesar 0,202 , ini berarti $20,2 \%$ variasi tinggi rendahnya motivasi belajar dapat dijelaskan secara bersama-sama oleh locus of control dan persepsi peserta didik tentang pendidikan, sedangkan sisanya $79,8 \%$ dijelaskan oleh variabel lain yang belum diteliti dalam penelitian ini.

\section{PEMBAHASAN}

\section{Locus of Control}

Hasil analisis data penelitian menunjukkan bahwa rata-rata secara keseluruhan peserta didik memiliki tingkat internal locus of control dalam kategori sedang. Hal ini berarti locus of control peserta didik cukup bagus. Berdasarkan pencapaian masing-masing indikator diketahui bahwa indikator internality berada pada kategori tinggi, sedangkan indikator powerful others dan chance berada pada kategori sedang. Kondisi locus of control (internality) yang tinggi ini perlu untuk terus dipertahankan, dikembangkan, dan ditingkatkan, karena locus of control merupakan suatu hal yang kompleks terkhusus dalam meningkatkan motivasi belajar.

Locus of control merupakan pandangan seorang individu terhadap dirinya, berkaitan dengan usaha dan hasil yang diterima. Setiap peserta didik mempunyai kecenderungan locus of control yang berbeda-beda, ada yang internal dan ada yang eksternal. Rotter (1966) mengungkapkan karakteristik locus of control internal peserta didik antara lain: perhatian yang penuh terhadap sesuatu, kompeten, dapat melawan dan mengatasi pengaruh dari luar, berorientasi pada prestasi, cekatan, dan percaya pada kemampuan sendiri. Hal tersebut terlihat jelas pada indikator internality bahwa peserta didik merasa yakin bahwa segala usaha dan hasil yang diterima ditentukan oleh kemampuan usaha sendiri. Rata-rata keluruhan peserta didik mencapai kategori tinggi, dan sangat tinggi. Ini menunjukkan bahwa rata-rata keseluruhan peserta didik sudah memiliki locus of control internal dan hal ini perlu dikembangkan. Selanjutnya dapat sebagai acuan bagi guru BK khususnya dalam mengarahkan peserta didik agar dapat mengembangkan locus of control internal tersebut dalam kehidupan sehari-hari peserta didik.

Di samping itu, capaian sedang pada indikator lainnya (powerful other dan chance) yang merupakan indikator yang mengarah pada locus of control eksternal perlu diperhatikan oleh guru BK pada khususnya dalam mengarahkan peserta didik kepada locus of control internal. peserta didik dengan locus of control eksternal berorientasi bahwa apa yang terjadi dalam hidupnya itu semua dipengaruhi oleh orang lain, keberuntungan, dan nasib yang diluar kendali mereka.

Berdasarkan data penelitian ini guru BK atau Konselor memegang peranan penting untuk mengarahkan locus of control peserta didik ke arah locus of control internal. Melalui pelayanan BK yang profesional diharapkan guru BK atau Konselor mampu mempertahankan, mengembangkan, maupun meningkatkan locus of control peserta didik. Hal ini dapat dilakukan oleh guru BK melalui layanan informasi dan layanan konseling individual. Dengan menginformasikan kepada peserta didik bagaimana pentingnya meningkatkan locus of control internal dalam kehidupan sehari-hari agar peserta didik menjadi pribadi yang mandiri dan pribadi yang percaya akan kemampuan sendiri serta sukses dalam belajar. Berdasarkan paparan tersebut dapat dipahami bahwa layanan informasi dan layanan konseling individual dapat dijadikan alternatif pelayanan oleh guru BK atau Konselor untuk meningkatkan locus of control peserta didik. 


\section{Persepsi Peserta Didik Tentang Pendidikan}

Berdasarkan hasil analisis data penelitian, bahwa secara rata-rata keseluruhan persepsi peserta didik tentang pendidikan berada pada kategori sangat positif. Pencapaian indikator pentingnya pendidikan dan tujuan dari pendidikan berada pada kategori sangat positif dan pencapaian pada indikator manfaat pendidikan berada pada kategori positif. peserta didik memiliki persepsi yang sangat positif tentang pendidikan dikarenakan peserta didik mengetahui dan memahami akan arti pentingnya pendidikan tersebut.

Secara utuh peserta didik telah mengenali dan menyadari akan arti penting dan tujuan dari pendidikan. Hal tersebut sesuai dengan pendapat Sternberg (2008) bahwa persepsi individu tentang sesuatu bukan hanya berasal dari tindakan mental, namun melibatkan proses yang panjang dimulai dari mengenali, mengorganisasikan, sampai pada memahami respon melalui tangkapan indera yang diterima dari lingkungan sekitar.

Berdasarkan rata-rata capaian persepsi peserta didik tentang pendidikan yang sangat positif, memberikan gambaran bahwa sangat bagusnya persepsi peserta didik tentang pendidikan dan hal ini menjadi acuan dan perhatian khusus bagi guru BK dalam mengarahkan peserta didik agar peserta didik mampu mempertahankan dan mengembangkan persepsi peserta didik yang sangat positiftentang pendidikan. Dalam hal ini yang perlu menjadi perhatian oleh guru BK adalah mengenai hasil dari indikator manfaat pendidikan yang berada pada kategori positif, dalam arti bagus. Guru BK berupaya mengarahkan agar peserta didik mampu meningkatkan persepsi tentang manfaat pendidikan tersebut pada kategori sangat positif, karena semakin lebih positif tentunya semakin bagus persepsi peserta didik tentang manfaat pendidikan.

Merujuk pada penelitian Afnibar (2011) secara konkret beberapa layanan yang dapat digunakan oleh guru BK atau Konselor untuk mengubah persepsi peserta didik tentang pendidikan menjadi lebih positif antara lain: layanan informasi, penempatan penyaluran, orientasi, maupun penguasaan konten. Layanan-layanan tersebut tentunya didukung oleh materi-materi yang sesuai dengan akan arti pentingnya pendidikan, tujuan dan manfaat pendidikan.

\section{Motivasi Belajar}

Hasil analisis data penelitian menunjukkan bahwa secara rata-rata keseluruhan motivasi belajar berada pada kategori tinggi. Berdasarkan pencapaian masing-masing indikator diketahui bahwa indikator tekun dalam mengerjakan tugas dan menunjukkan minat berada pada ketegori tinggi, sedangkan indikator ulet dalam menghadapi kesulitan dan mandiri dalam belajar berada pada kategori sedang.

Hal ini terlihat jelas bahwa masih adanya motivasi belajar peserta didik yang rendah dan tentunya ada berbagai faktor yang menyebabkan rendahnya motivasi belajar peserta didik tersebut. Secara rata-rata keseluruhan memang motivasi belajar peserta didik berada pada ketegori tinggi, namun karena ada beberapa item yang berada pada kategori sedang, tentunya hal tersebut perlu dibahas.

Motivasi belajar dalam kategori tinggi ini perlu dipertahankan dan lebih dikembangkan oleh peserta didik. Sedangkan motivasi belajar yang sedang perlu menjadi perhatian khusus oleh guru BK. Syah (2001) mengemukakan bahwa motivasi belajar dipengaruhi oleh 2 faktor, yaitu: (1) faktor internal yang meliputi sikap, kepribadian, pendidikan, pengalaman, dan cita-cita, (2) faktor eksternal yang meliputi lingkungan sosial, yang terdiri dari lingkungan masyarakat, tetangga, teman, orangtua/ keluarga, dan teman sekolah. Lingkungan non sosial, yang terdiri dari keadaan gedung sekolah, letak sekolah, jarak tempat tinggal dengan sekolah, alat-alat belajar, kondisi ekonomi orangtua, dan lain-lain. Beberapa faktor yang lain selain dari locus of control dan persepsi tersebut kemungkinan juga mempengaruhinya motivasi belajar. 
Berbagai faktor tersebut dapat sebagai acuan oleh guru BK untuk menindaklanjuti lebih lanjut hal apa yang mempengaruhi motivasi belajar peserta didik tersebut. Guru BK dapat memberikan layanan informasi, konseling individual, bimbingan kelompok, konseling kelompok dan penguasaan konten terhadap peserta didik.

\section{Hubungan antara Locus of Control dengan Motivasi Belajar}

Hasil penelitian menunjukkan bahwa locus of control memiliki hubungan yang signifikan dengan motivasi belajar. Temuan ini diperoleh berdasarkan rangkaian analisis data, yang menunjukkan bahwa $4 \%$ motivasi belajar dijelaskan oleh locus of control. Artinya, locus of control merupakan salah satu faktor yang berhubungan dengan motivasi belajar. Hal ini juga sesuai dengan pendapat Elliot dkk. (1996) bahwa locus of control merupakan salah satu faktor yang mempengaruhi motivasi belajar. Selanjutnya hal ini juga sesuai dengan hasil penelitian dari Mugiarso dan Suharso (2013), yang menyatakan bahwa seseorang yang cenderung memiliki locus of control internal, berarti seseorang tersebut memiliki motivasi yang tinggi, dalam arti terdapatnya hubungan yang signifikan antara locus of control dengan motivasi belajar.

Selanjutnya, hasilpenelitianinimemberikan gambaran bahwa meskipun hubungan antara locus of control dengan motivasi belajar hanya $4 \%$, hal ini tidak serta merta dapat diabaikan, karena sudah terbukti bahwa locus of control akan mendorong peserta didik untuk dapat meningkatkan motivasi belajarnya.

Oleh sebab itu, guru BK atau Konselor mempunyai peranan yang cukup strategis terhadap hal ini. Guru BK atau Konselor harus tetap mengembangkan dan meningkatkan locus of control peserta didik, agar peserta didik dapat meningkatkan motivasi belajarnya. Melalui pelayanan BK yang optimal locus of control peserta didik harus terus dikembangkan, karena secara langsung berdampak pada motivasi belajar peserta didik. Salah satu layanan yang dapat digunakan guru BK atau Konselor untuk meningkatkan motivasi belajar peserta didik adalah layanan informasi, dengan memberikan berbagai informasi-informasi terkait dengan pentingnya percaya akan suatu usaha dan hasil yang diperoleh merupakan upaya yang dilakukan oleh diri sendiri agar peserta didik menjadi pribadi yang selalu dapat memotivasi dirinya sendiri dalam belajar.

\section{Hubungan Persepsi peserta didik tentang Pendidikan dengan Motivasi Belajar}

Hasil penelitian menunjukkan bahwa persepsi peserta didik tentang pendidikan memiliki hubungan yang signifikan dengan motivasi belajar. Temuan ini diperoleh berdasarkan rangkaian analisis data, yang menunjukkan bahwa 18,6\% motivasi belajar dijelaskan oleh persepsi peserta didik tentang pendidikan. Artinya, persepsi peserta didik tentang pendidikan merupakan salah satu faktor yang berhubungan dengan motivasi belajar.

Merujuk pada data penelitian ini dapat dipahami bahwa semakin positif persepsi peserta didik tentang pendidikan maka akan semakin tinggi pula motivasi belajar peserta didik. Hal ini sesuai dengan temuan penelitian Megawati (2015) yang menyatakan bahwa semakin positif persepsi peserta didik, maka akan semakin menumbuhkan motivasi belajar yang tinggi pada peserta didik, dan semakin tidak positif persepsi peserta didik, maka akan semakin rendah juga motivasi belajar peserta didik tersebut. Dapat disimpulkan bahwa salah satu faktor yang mempengaruhi motivasi belajar adalah persepsi peserta didik tentang pendidikan.

Berdasarkan pemaparan di atas, dapat dipahami bahwa begitu berpengaruhnya persepsi peserta didik tentang pendidikan dalam meningkatkan motivasi belajar peserta didik. Tingginya motivasi belajar peserta didik salah satunya dipengaruhi oleh persepsi peserta didik tentang pendidikan. Oleh sebab itu, guru BK atau Konselor perlu memahami bahwa untuk meningkatkan motivasi belajar peserta didik, persepsi peserta didik tentang pendidikan 
terlebih dahulu yang harus diubah menjadi lebih positif, sesuai dengan pendapat Sarwono (2012) bahwa persepsi merupakan tahap awal peserta didik dalam menginterpretasikan sesuatu. Guru BK atau konselor dapat memberikan layanan informasi berupa pentingnya pendidikan dan apa manfaat dari pendidikan tersebut, agar peserta didik dapat meningkatkan motivasi belajarnya.

\section{Hubungan Locus of Control dan Persepsi peserta didik tentang Pendidikan dengan Motivais Belajar}

Hasil penelitian menunjukkan bahwa locus of control dan persepsi peserta didik tentang pendidikan secara bersama-sama memiliki hubungan yang signifikan dengan motivasi belajar. Temuan ini diperoleh berdasarkan rangkaian analisis data, yang menunjukkan bahwa 20,2\% motivasi belajar dijelaskan oleh locus of control dan persepsi peserta didik tentang pendidikan. Berdasarkan hasil penelitian diperoleh gambaran bahwa locus of control dan persepsi peserta didik tentang pendidikan tidak terlalu berbeda memiliki hubungan dengan motivasi belajar. Jika membandingkan keduanya maka persepsi peserta didik tentang pendidikan memiliki hubungan yang kuat dengan motivasi belajar dibandingkan dengan locus of control.

Locus of control merupakan pandangan peserta didik terhadap dirinya, berkaitan dengan usaha dan hasil yang diterima. Semakin tinggi locus of control peserta didik maka motivasi belajar peserta didik pun akan semakin tinggi. Hal ini sesuai dengan pendapat dari Mugiarso dan Suharso (2013), yang menyatakan bahwa seseorang yang cenderung memiliki locus of control internal, berarti seseorang tersebut memiliki motivasi yang tinggi, dalam arti terdapatnya hubungan yang signifikan antara locus of control dengan motivasi belajar.

Selanjutnya persepsi tentang pendidikan merupakan tahap awal yang menentukan meningkatnya motivasi belajar peserta didik. Dengan semakin positifnya persepsi peserta didik tentang pendidikan, maka akan semakin meningkatkan motivasi belajar peserta didik. Hal ini sesuai dengan hasil temuan penelitian Megawati (2015) yang menyatakan bahwa semakin positif persepsi peserta didik, maka akan semakin menumbuhkan motivasi belajar yang tinggi pada peserta didik, dan semakin tidak positif persepsi peserta didik, maka akan semakin rendah juga motivasi belajar peserta didik tersebut.

Berdasarkan nilai $\mathrm{R}^{2}$ motivasi belajar dijelaskan sebesar 20,2\% oleh locus of control dan persepsi peserta didik tentang pendidikan, kemudian 79,2\% lagi kemungkinan dijelaskan oleh faktor lain yang belum diteliti pada penelitian ini. Hal ini terlihat bahwa locus of control dan persepsi peserta didik tentang pendidikan secara bersama-sama tidak terlalu besar mempengaruhi motivasi belajar. Keadaan ini dapat dipahami, karena sesungguhnya masih banyak variabel lainnya yang mempengaruhi motivasi belajar.

Bila merujuk pada teori Elliott dkk. (1996) faktor yang mempengaruhi motivasi belajar kemungkinan dari segi lainnya yaitu anxiety (kecemasan), attitudes (sikap), curiosity (keingintahuan), learned helplessness (kekurangmampuan dalam belajar), self efficacy (keyakinan diri), dan cooperative learning (pembelajaraan kooperatif). Dan dapat juga dilihat dari pendapat Syah (2001) yang mengemukakan bahwa motivasi belajar dipengaruhi oleh 2 faktor, yaitu: (1) faktor internal yang meliputi sikap, kepribadian, pendidikan, pengalaman, dan cita-cita, (2) faktor eksternal yang meliputi lingkungan sosial, yang terdiri dari lingkungan masyarakat, tetangga, teman, orangtua/keluarga, dan teman sekolah. Lingkungan non sosial, yang terdiri dari keadaan gedung sekolah, letak sekolah, jarak tempat tinggal dengan sekolah, alat-alat belajar, kondisi ekonomi orangtua, dan lainlain. Dapat dikatakan bahwa faktor lainlah yang juga mempengaruhi motivasi belajar selain dari locus of control dan persepsi peserta didik tentang pendidikan yang peneliti lakukan ini.

Beberapa paparan di atas membuktikan bahwa locus of control dan persepsi peserta 
didik tentang pendidikan secara bersamasama memiliki hubungan yang signifikan dengan motivasi belajar. Dengan demikian untuk meningkatkan motivasi belajar, dapat diupayakan dengan meningkatkan locus of control dan mengupayakan peserta didik mempunyai persepsi yang positif tentang tentang pendidikan. Guru BK atau Konselor juga berperan dalam memberikan layanan kepada peserta didik untuk meningkatkan motivasi belajar peserta didik, seperti layanan konseling individual, dengan menulusuri apa penyebab dari rendahnya motivasi belajar peserta didik tersebut. Berbagai faktor selain dari locus of control dan persepsi peserta didik tentang pendidikan yang sudah dijelaskan di atas, dapat dijadikan sebagai acuan bagi guru BK atau Konselor dalam memberikan layanan kepada peserta didik agar peserta didik dapat meningkatkan motivasi belajarnya.

\section{KESIMPULAN}

Berdasarkan temuan dan pembahasan hasil penelitian, maka dapat dikemukakan kesimpulan sebagai berikut:

1. Secara rata-rata tingkat internal locus of control peserta didik SMA Pertiwi 1 Padang berada pada kategori sedang. Hal ini berarti internal locus of control peserta didik termasuk kategori cukup bagus.

2. Secara rata-rata persepsi peserta didik SMA Pertiwi 1 Padang tentang pendidikan berada pada kategori sangat positif. Hal ini berarti persepsi peserta didik tentang pendidikan termasuki kategori sangat bagus.

3. Secara rata-rata motivasi belajar peserta didik SMA Pertiwi 1 Padang berada pada kategori tinggi. Hal ini berarti motivasi belajar peserta didik termasuk kategori bagus.

4. Locus of control memiliki hubungan yang signifikan dengan motivasi belajar di SMA Pertiwi 1 Padang. Hasil penelitian menunjukkan koefisien korelasi (R) sebesar 0,200 dan $R^{2}$ sebesar 0,040 , yang berarti bahwa $4 \%$ motivasi belajar dijelaskan oleh locus of control.
5. Persepsi peserta didik tentang pendidikan memiliki hubungan yang signifikan dengan motivasi belajar di SMA Pertiwi 1 Padang. Hasil penelitian menunjukkan koefisien korelasi (R) sebesar 0,432 dan $\mathrm{R}^{2}$ sebesar 0,186 , yang berarti bahwa $18,6 \%$ motivasi belajar dijelaskan oleh persepsi peserta didik tentang pendidikan.

6. Locus of control dan persepsi peserta didik tentang pendidikan secara bersamasama memiliki hubungan yang signifikan dengan motivasi belajar di SMA Pertiwi 1 Padang. Hasil penelitian menunjukkan koefisien korelasi (R) sebesar 0,449 dan $\mathrm{R}^{2}$ sebesar 0,202, yang berarti $20,2 \%$ motivasi belajar dijelaskan oleh locus of control dan persepsi peserta didik tentang pendidikan. Artinya tinggi rendahnya motivasi belajar tidak hanya dipengaruhi oleh satu variabel saja (locus of control dan persepsi peserta didik tentang pendidikan), namun dipengaruhi secara bersama-sama oleh locus of control dan persepsi peserta didik tentang pendidikan. Atau dengan kata lain dapat dikatakan bahwa semakin tinggi locus of control dan semakin positif persepsi peserta didik tentang pendidikan, maka semakin tinggi motivasi belajar peserta didik. Hal ini berarti variabel locus of control dan persepsi peserta didik tentang pendidikan akan lebih efektif jika dikombinasikan secara bersama-sama sebagai prediktor untuk meningkatkan motivasi belajar daripada hanya satu variabel saja.

\section{SARAN}

Berdasarkan hasil penelitian, pembahasan, dan kesimpulan yang telah dikemukakan sebelumnya, maka terdapat beberapa saran yang dapat direkomendasikan sebagai berikut:

1. Kepada guru BK atau Konselor di sekolah disarankan untuk mengarahkan peserta didik yang memiliki locus of control eksternal ke arah locus of control internal. Guru BK atau Konselor juga disarankan untuk memberikan arahan dalam meningkatkan motivasi belajar 
peserta didik, seperti memberikan arahan bagaimana cara menghadapi tugas yang sulit dan bagaimana supaya peserta didik dapat mandiri dalam belajar.

2. Kepada wali kelas dan guru bidang studi di sekolah disarankan agar tetap saling bekerja sama dengan guru BK atau konselor dalam memberikan arahan untuk meningkatkan motivasi belajar peserta didik.

3. Kepada kepala sekolah disarankan untuk dapat memberikan dukungan penuh kepada guru BK atau Konselor, dengan memfasilitasi sebaik mungkin pelaksanaan masuk kelas 2 jam pembelajaran setiap minggu, maupun pelaksanaan layanan BK di luar jam pembelajaran. Kepala sekolah diharapkan dapat memberikan ruang yang cukup bagi peserta didik untuk memberikan masukan, kritikan, dan saran dalam rangka meningkatkan motivasi belajar peserta didik.

\section{DAFTAR RUJUKAN}

$\begin{array}{clr}\text { Afnibar. (2011). } & \text { "Model } & \text { Pelayanan } \\ \text { Konseling } & \text { Format } & \text { Klasikal } \\ \text { dalam Kegiatan } & \text { Belajar peserta didik". } \\ \text { Disertasi tidak } & \text { diterbitkan. Padang: } \\ \text { Program Pascasarjana } & \text { Universitas } \\ \text { Negeri Padang. } & \end{array}$

Crider, A. B. (1983). Psychology. Glenview, Illinois: Scott Foresman and Company: United State of America.

Elliott, S.N. \& Travers, J.F. (1996). Educational Psychology: Effective teaching, effective learning. Dubuque: Brown \& Benchmark.

Loice, M. C. (2014). The Influence of Locus of Control on Employees' Perceptions of The Effectiveness of Performance Appraisal at Kenya Revenue Authority (Southern Region). A research Project Submitted in Partial Fulfillmentof the Requirements for the Award of The Degree of Master of Business Administration (MBA), (Online), (www.erepository.
ounbi.ac.ke/.../Mutai.The\%20influen, diakses 11 September 2015).

Mangkuprawira, TB. S. \& Hubeis, A. V. (2007). Manajemen Mutu Sumber Daya Manusia. Bogor: Ghalia Indonesia.

Megawati, L. (2015). Persepsi peserta didik tentang Mata Pelajaran Matematika dan Hubungannya dengan Motivasi Belajar serta Implikasinya dalam Pelayanan Bimbingan Konseling di SMPN 25 Pekanbaru. (Unpublished Master's Thesis). Universitas Negeri Padang, Padang.

Mugiarso, C. H \& Suharso. (2013). Hubungan locus of control dengan motivasi konselor dalam layanan konseling perorangan. Indonesian Journal Of Guidance And Counseling: Theory And Application, 2(3), 41-49.

Nirwana, H. (2003). Hubungan Tingkat Aspirasi dan Persepsi tentang Belajar dengan Hasil Belajar Matematika peserta didik Sekolah Menengah Umum yang Berlatar Belakang Budaya Minangkabau dan Batak. (Unpublished Dissertation) Universitas Negeri Malang, Malang.

Rotter, J.B. (1966). Generalized Expectancies for Internal Versus External Control of Reinforcement. American Psychological Association, 80(1), 1-28.

Sarwono, S. W. (2012). Pengantar Psikologi Umum. Jakarta: Rajagrafindo Persada.

Sobur, A. (2003). Psikologi Umum. Bandung: Pustaka Setia.

Sternberg, R. J. (2008). Psikologi Kognitif Edisi Keempat (Y. Santoso, Trans.). Yogyakarta: Pustaka Pelajar.

Suryabrata, S. (2012). Psikologi Pendidikan. Jakarta: Raja Grafindo Persada.

Syah, M. (2001). Psikologi Belajar. Jakarta: Logos Wancana Ilmu. 